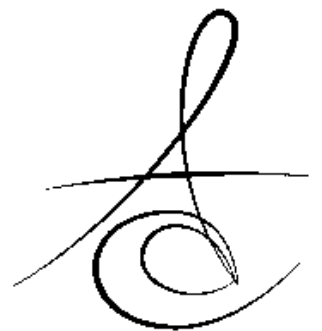

\title{
DENTAL VOLUMETRIC TOMOGRAPHY IN THE RADIOLOGICAL DETECTION OF ZYGOMATICO - ORBITO - MAXILLARY COMPLEX FRACTURE
}

\section{ZİGOMATİKO-ORBİTO-MAKSİLLER KOMPLEKS KIRIĞININ RADYOLOJİK TESPİTİNDE DENTAL VOLÜMETRİK TOMOGRAFİ}

\author{
Yrd. Doç. Dr. Muhammed Akif SÜMBÜLLÜ*
}

Doç. Dr. Binali ÇAKUR*

Makale Kodu/Article code: 1034

Makale Gönderilme tarihi: 14.01 .2013

Kabul Tarihi: 05.04.2013

\section{ABSTRACT}

Facial trauma could result in one or more bone fractures. Facial bone fractures most frequently occur in the zygoma or mandible. Radiography plays a crucial role for diagnosis and management of traumatic injuries. In this case report, we presented a 30-year-old male patient with zygomatico - orbito maxillary complex (ZOMC) fracture determined with dental volumetric tomography (DVT) scans. DVT provides three-dimensional images and has provided useful diagnosis and treatment planning for midfacial fractures.

Key words: Dental volumetric tomography; diagnosis; facial fracture

\section{ÖZET}

Yüz travması bir veya daha fazla kemik kırıkları ile sonuçlanabilir. Yüz kemiği kırıkları sık olarak zigoma veya mandibulada oluşur. Radyografi travmatik hasarların teşhisinde kritik bir öneme sahiptir. $\mathrm{Bu}$ vaka raporunda dental volümetrik tomografi ile tespit edilmiş zigomatiko- orbitomaksiller kompleks kırığı bulunan 30 yaşında erkek bir hastayı sunduk. Üç boyutlu görüntüler elde edilebilen dental volümetrik tomografi orta yüz kırıklarının teşhisi ve tedavi planlamasında faydalı bilgiler sağlar.

Anahtar kelimeler: Dental volümetrik tomografi, teşhis; yüz kırığı

\section{INTRODUCTION}

The midfacial region comprises the medial portion of the face including the upper maxillary region and the $\mathrm{ZOMC}{ }^{1} \mathrm{ZOMC}$ is also located in the midface laterally, which determines the cubic structure of the facial figure in three-dimensions. ZOMC plays an important role in the structure, function and aesthetic appearance of the facial skeleton. It has also a role in vision and mastication. ${ }^{2}$ The face occupies the most prominent position in the human body rendering it vulnerable to injuries quite commonly. ${ }^{3}$ The forward projection of the zygoma causes it to be injured frequently in the face. ${ }^{4}$ However, trauma to the zygomatic bone is rarely resulting in fracture itself. But its' weaker processes and their surrounding attachments are generally fractured and displaced. ${ }^{5}$ The zygoma sutures with the frontal, maxillary, temporal and sphenoid bones and it contributes
Thus, ZOMC fractures are often accompanies by adjacent bone fracture especially when the trauma is causes by a direct strong force with high energy and it involve the orbital floor. ${ }^{2,6}$ For this reason, there are lots of terms for such fractures such as zygomatic complex fracture, orbital maxillary zygomatic fracture, zygomatic maxillary complex fracture, orbital zygomatic fracture, and tetrapod fracture etc. ${ }^{2}$ The frequency of ZOMC fractures is second only to nasal fractures, which are the most common type of facial fracture. ${ }^{7}$

Previous reports indicated that the incidence of the ZOMC fracture was about $18 \%-43.9 \% .^{2}$ The most common causes of ZOMC fractures include personal altercations, falls, motor vehicle accidents, and sports injuries. ${ }^{6}$ A much higher percentage of ZOMC fractures occur in males $(80 \%)$ than in female $(20 \%)$. The majority of patients are young male in their third decade of life. Many authors have devised

*Department of Oral Diagnosis and Radiology, Ataturk University, Faculty of Dentistry,Erzurum, Turkey

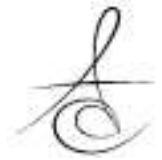


classification schemes for ZOMC fractures. ${ }^{4,} 7$ These classification schemes are of little clinical significance. However, they are helpful in research and physician communication. ${ }^{7}$

This case report focuses on the radiological diagnosis of a zygomatico - orbito - maxillary complex and nasal bone fractures by using cone beam computed tomography in an adult person.

\section{CASE HISTORY}

A 30-year-old male patient visited to our clinic for a facial trauma due to fighting about a few years ago. The facial examination revealed a zygomatic complex fracture complains of pain, periorbital edema and depression of the zygomatic arch, subconjunctival hemorrhage, antimongoloid slant and enophthalmus. Then we decided to perform a dental volumetric computed tomography scans for obtaining more detailed location and definition of the fracture. We used dental volumetric tomography in our department (NewTom FP, Quantitative Radiology, Verona, Italy). DVT scanning was done on supine patient; the patient's head was adjusted in such a way that the hard palate was parallel to the floor while the sagittal plane was perpendicular o the floor. The DVT scans with $0.5 \mathrm{~mm}$ axial slices, $2 \mathrm{~mm}$ coronal slices, $2 \mathrm{~mm}$ sagittal slices and $3 \mathrm{D}$ images were obtained. Imaging parameters were kV, 110; mA, 15; and FOV, $130 \mathrm{~mm}$. The output was automatically adjusted during a $360^{\circ}$ rotation according to tissue density (automatic exposure control system). In the images, we saw the ZOMC fracture and fractures of nasal bones. We also observed separation of nasomaxillary, zygomaticofrontal, zygomaticomaxillary sutures and posttraumatic enophthalmus in the left side of the face of the patient (Figs. 1-3). There were no problems his general medical history. The patient referred to department of maxillofacial surgery to the treat the fractures of ZOMC and nasal bone.

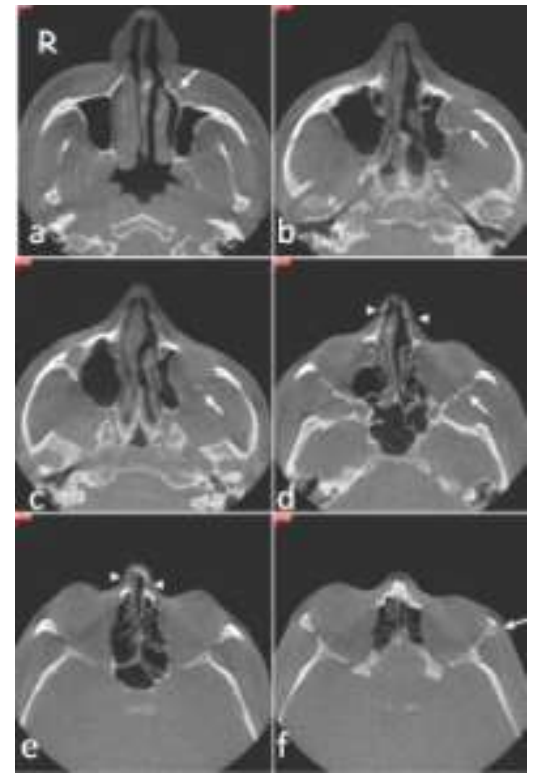

Fig. 1 Zygomaticomaxillary complex fracture and orbital blowout fracture, sequential axial slices; On the left,

(a) collapsed anterior surface of maxilla (white arrow),

(b) and (c) collapsed of orbita floor and apex (white arrow),

(d) and (e) fracture of nasal bone and separation of nasomaxillary suture (arrowhead),

(f) zygomaticofrontal suture separation (white arrow).

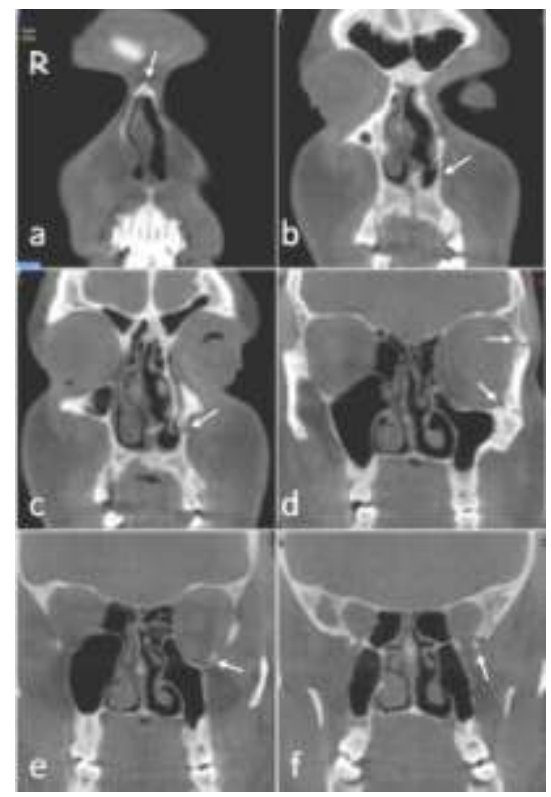

Fig. 2 Zygomaticomaxillary complex fracture and orbital blowout fracture, sequential coronal slices; On the left,

(a) fracture of nasal bone and nasomaxillary suture separation (white arrow),

(b) and (c) fracture of maxillary bone (white arrow) and post-traumatic left enophthalmos

(d) separation of zygomaticofrontal and zygomaticomaxillary suture (white arrow),

(e) and (f) collapsed of orbita floor and apex (white arrow).

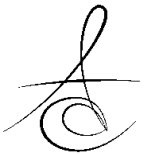




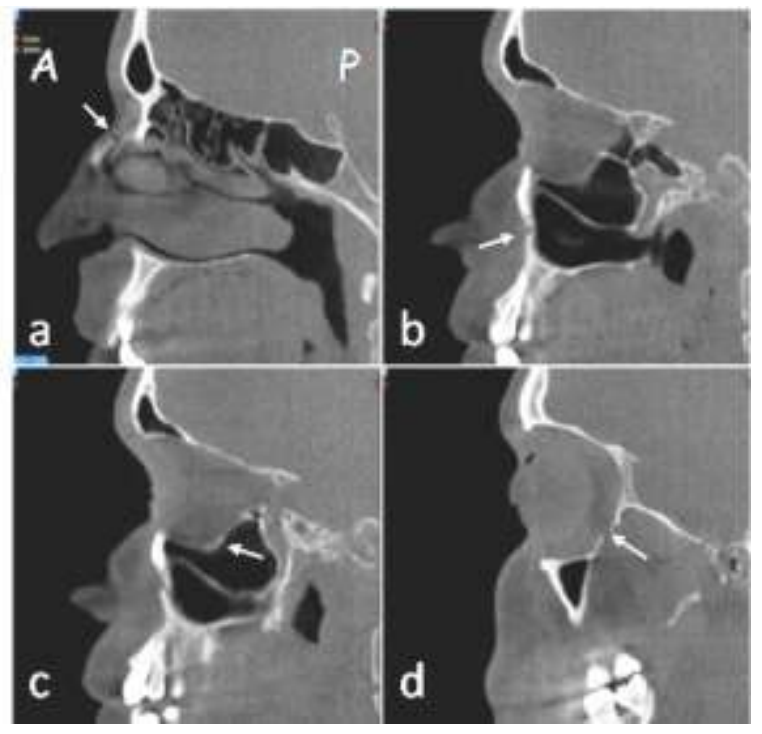

Fig. 3 Zygomaticomaxillary complex fracture and orbital blowout fracture, sequential sagittal slices; On the left,

(a) fracture of nasal bone (white arrow),

(b) fracture of maxillary bone (white arrow),

(c) and (d) post-traumatic left enophthalmos and collapsed of orbita floor and apex (white arrow).

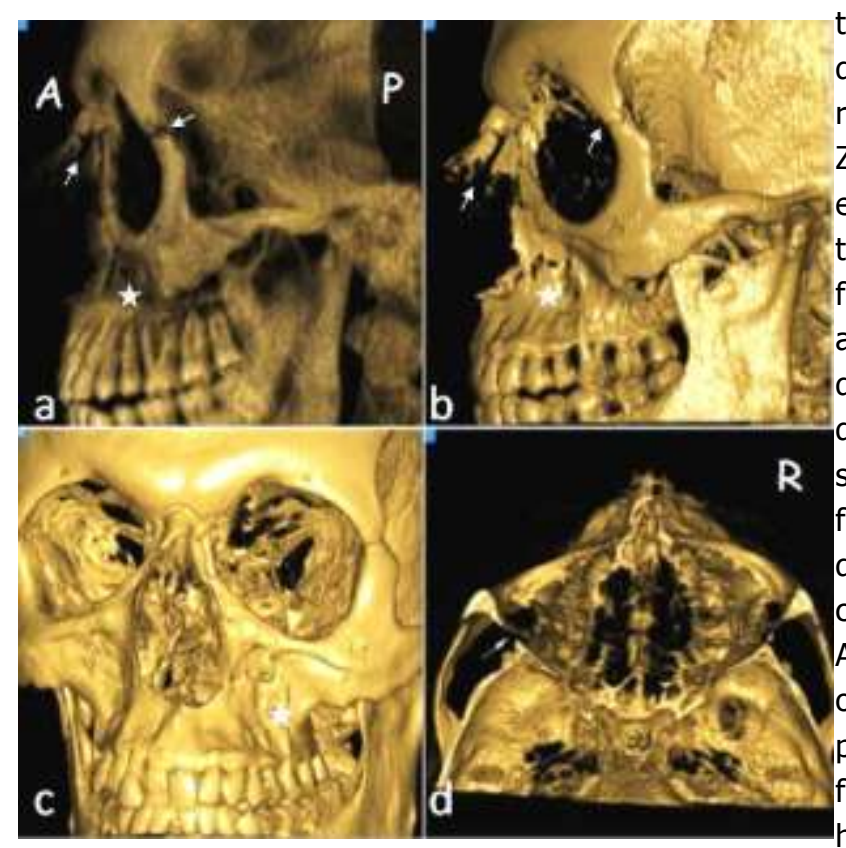

Fig. 4 Zygomaticomaxillary complex fracture and orbital blowout fracture, 3D-DVT reconstructed images; On the left,

(a) and (b) fracture of nasal bone (white arrow), fracture of maxillary bone (white star) and separation of zygomaticofrontal suture

(c) fracture of maxillary bone (white star), (d) orbital blowout fracture (white arrow).

\section{DISCUSSION}

Zygomatic fractures are not life threatening and are usually treated. But it is associated with functional, aesthetic and neurological problems because of its anatomical relationships. ${ }^{3}$ Thus, clinical examination augmented with radiological investigation is very important and gives an accurate diagnosis regarding the extent of injuries. ${ }^{3}$ In ZOMC fracture, there is a rotation and displacement. The distance and direction of displacement may suggest the severity of the force causing the wound. ${ }^{2}$ In the clinical examination, limitation of jaw movement and flattening of the cheek, unilateral epistaxis, paresthesia or anesthesia in the distribution of the infraorbital nerve, unequal pupil heights and a decrease in extraocular muscle function with diplopia usually are seen. ${ }^{5}$ If can not be treat correctly in time, symptoms will at last have a bad effect on the normal live and social activities of the patients and deformities of ZOMC fracture will occur. ${ }^{2}$ In the radiological examination, plain radiograph and computed tomography (CT) scan were effective in aiding the diagnosis of these fractures. Traditional facial radiographs have limited usefulness in the diagnosis of ZOMC fractures. ${ }^{7}$ The submentovertex view offers excellent resolution of the zygomatic arches. However, the single best radiograph for evaluation of ZOMC fracture is Water's view. ${ }^{4,7}$ The dense temporal bone and other superimpositions make subtle findings difficult in this region. Even if a facial fracture is diagnosed using plain radiographs, CT is the gold standard for radiographic evaluation of zygomatic fracture. ${ }^{7}$ Axial and coronal images are obtained to define fracture patterns, degree of displacement and communities and to evaluate the orbital soft tissues. Axial CT scans do not clearly define the extent of orbital blowout fractures. However, coronal views are particularly helpful in the evaluation of orbital floor fracture. ${ }^{4}$ In addition, it is useful to evaluate for herniation of orbital tissues into the maxillary sinus (Figs. 1 and 2). The 3-D reconstruction are of immense help as it shows the areas of fracture (Fig. 3 ), and are effective in preoperative planning. ${ }^{3}$ DVT has been introduced in preoperative dental imaging and has gained increased acceptance. ${ }^{8,9,10}$ DVT requires less radiation exposure than conventional $\mathrm{CT}$. Preclinical studies revealed that high contrast

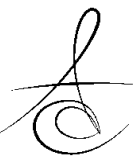


structures of the facial skeleton can be visualized in a comparable quality to CT. Furthermore, DVT do not cause artifacts by plane leaps in secondary reconstructions. ${ }^{8}$ Although both ZOMC fracture and nasal fracture was observed, the mandible and other structures of the face were intact in our case. In our opinion, to avoid any negative consequences on the performance or success of the surgical intervention, the ZOMC fractures should be evaluated as the examination of whole maxillofacial region including the mandible. The ratio in previous studies is $4.7: 1 .^{3}$ Chowdhury ${ }^{3}$ and Karyouti ${ }^{11}$ reported 5.2:1 - 8:1 respectively. The young in their third decade of life most frequently involve with the fracture because of more active physically. ${ }^{3}$ In our case report, the male patient was in third decade of life but a facial trauma occurred due to fighting about a few years ago. Chowdhury and Menon ${ }^{3}$ reported that the right side of the face was most frequently involved, in our case, the left of the face was involved and this may be because of different for hand use.

In summary, the whole face evaluation is important during the initial evaluation of ZOMC fractures. The CT scan is often essential in the evaluation for surgery. Dental volumetric tomography can offer an alternative to preoperative CT examinations requiring less radiation exposure as well as less financial and personal effort.

\section{REFERENCES}

1. Almadori GRG, Corina L, Parrilla C, Rigante M, Ottaviani $F$. Midfacial fractures: Our experience. Acta Otorhinolaryngol ital 2003;23:265-73.

2. Sun $Y$, Tang $Y$, $X u B$, Peng $L$, Lu $Q$, Qiao $J$ et al. Establishment of a new method for quantitative diagnosis of zygomatic complex fractures with three dimensional CT. J Chinese Clin Med 2006;1:257-63.

3. Chowdhury SKR, Menon PS. Etiology and management of zygomaticomaxillary complex fractures in the armed forces. MJAFI 2005; 61:238-40.

4. Bailey JS, Goldwasser MS. Management of zygomatic complex fractures. In: Michael Miloro, ed. Peterson's Principles of Oral and Maxillofacial Surgery, 2nd edn. London: BC Decker Inc. 2004; 445-62.
5. Gerlock AJ, Sinn DP. Anatomic, Clinical, Surgical, and Radiographic Correlation of the Zygomatic Complex Fracture Am J Roentgenol 1977; 128:235-8.

6. Maturo S, Lopez MA. Zygomatico-orbito-maxillary complex fractures. Operative Techniques in Otolaryngology 2008;19: 86-9.

7. Strong EB. Maxillary zygomatic fractures. eMedicine 2007.

8. Heiland M, Schulze $D$, Blake F, Schmelzle R. Intraoperative imaging of zygomaticomaxillary complex fractures using a 3D C-arm system. Int J Oral Maxillofac Surg 2005;34:369-75.

9. Çakur B, Sümbüllü MA. Konik ışınlı bilgisayarlı tomografi ile submandibular tükürük bezi taşı görüntülemesi. Atatürk Üniv Diş Hek Fak Derg 2010;20:194-7.

10. Çakur B, Sümbüllü MA, Yılmaz AB. Alt Konka Hipertrofisi, Nazal Septum Deviasyonu ve Antral Retansiyon Kisti Arasındaki İliş̧i. Atatürk Üniv Diş Hek Fak Derg 2011;21:5-9.

11. Karyouti SM. Maxillofacial injuries in Jordan University hospital; Int J Oral Maxillofacial Surgery 1987: 16,262-5.

\author{
Yazışma Adresi \\ Dr. Binali ÇAKUR \\ Ataturk University \\ Faculty of Dentistry \\ Department of Oral Diagnosis and Radiology, \\ 25240 Erzurum / TURKEY \\ Business telephone number: +90.442 .2311765$ \\ Fax number: +90.442 .2360945$ \\ E-mail address: bcakur@atauni.edu.tr
}

